\title{
Editorial: Discrimination laws and pension schemes - An expensive minefield
}

Lawyers advising people who run pension schemes are used to queries about anti-discrimination laws. While there are already many such laws in place, the Government plans to widen the types of behaviour which count as discrimination, as it has been doing since 1995. This is an overview of anti-discrimination laws as they apply to occupational pension schemes.

Are we just talking about sex discrimination? No - the range of activities caught by anti-discrimination laws continues to widen. We have all heard of sex discrimination. Over the last eight years, new laws have been brought in to protect people with disabilities and to protect part-timers and fixed-term employees. The Government is planning more legislation which will cover other instances of discrimination relating to a person's age or sexual orientation. Plans are also afoot to strengthen the existing laws on disability discrimination.

\section{Sex discrimination}

Having said that sex discrimination is not the only sort of discrimination, I will deal with it first, if only because it has received the most column inches. Sex discrimination can either be direct or indirect. In the pensions context, direct discrimination would involve expressly limiting benefits or eligibility to join the pension scheme to persons of a particular sex. As you would expect, this sort of discrimination is now very rare. Indirect sex discrimination is far more prevalent. The definition of indirect sex discrimination varies according to the legislation or case law that a claimant is relying upon. Broadly, though, indirect sex discrimination takes place when the people who are able to join a scheme or obtain higher benefits are made up of a significantly greater proportion of people of one sex. Indirect sex discrimination is often unintentional and may well be present at the same time as the other forms of discrimination outlined in this editorial.

There has been extensive press coverage of the 60,000 or so claims brought by part-time workers alleging indirect sex discrimination. Those claimants alleged that their exclusion from their employer's pension scheme because of their part-time status constituted indirect sex discrimination in breach of European law. The law in question is set out in Article 141 of the Treaty of Rome, which requires equal pay for male and female workers for equal work or work of equal value. In February 2001, the House of Lords ruled that people claiming under Article 141 had to bring their claims within six months of leaving employment (Preston $v$. Wolverhampton Healthcare NHS Trust). Employers were surprised by the other part of the ruling, which allowed claimants to claim retrospective pension scheme membership as far back as 1976 (when a judgment handed down by the ECJ first said that Article 119 (now 141) 
of the Treaty was directly enforceable by employees against their employer).

Many questions concerning backdated membership of pension schemes remain unanswered and are too numerous to mention here. Employers wishing to defend the claims will need to show that part-timers were excluded for a good reason unrelated to their sex (although nobody quite knows what would count as a good reason). Although most indirect sex discrimination claims have been brought by part-timers, any kind of employee could bring a claim if the sex profile of the workforce supports the claim.

Not letting people into a pension scheme is one aspect of sex discrimination. Calculating benefits under the pension scheme in a way that discriminates against one sex is another aspect. Case law has established that equal benefits need to be provided from 17th May, 1990 (the date of the Barber v. Guardian Royal Exchange judgment in the ECJ). Again, there are several unanswered questions as regards benefits and sex discrimination. For example, the position for schemes which integrate their benefit structures with those of the state is unclear.

Domestic legislation dealing with sex discrimination and pensions can be found in the Equal Pay Act 1970 (amended by the Pensions Act 1995) and the Sex Discrimination Act (SDA) 1975. It is worth noting that the SDA has been amended so that indirect sex discrimination has been extended to include not just discriminatory provisions or criteria but also discriminatory practices (this is in line with the Employment Directive, 2000/78/EC).

\section{Part-timers}

Although several part-timers have brought claims based on laws dealing with indirect sex discrimination, UK law also requires that part-time workers should not be treated less favourably than full-time workers, regardless of whether any sex discrimination has taken place (SI 2000/1551). A part-time worker would need to compare his or her treatment with the treatment afforded to a full-time worker who does similar work or work of the same sort of value for the same employer, if possible working at the same establishment. As with a sex discrimination claim, the employer can defend itself by putting forward a good reason for the less favourable treatment.

\section{Disability discrimination}

The Disability Discrimination Act 1995 was introduced to protect disabled people from being treated less favourably than able-bodied people by their employer or by the trustees of a pension scheme. But there are certain exemptions when it comes to pensions. The legislation says that where the cost of providing certain benefits is likely to be substantially greater for a disabled person then the discrimination is justified. The legislation also expressly accepts as justifiable the practice of requiring a disabled person to pay the same rate of contribution to the pension scheme as someone who is not disabled, even though the disabled person will not be eligible for certain benefits because of his or her disability. If one of these exemptions does not apply and the employer or trustees can show that there is a material and substantial reason for treating disabled people differently and that reason is justified, then the claim can be successfully defended.

Although employers must make adjustments when a disabled person is at a substantial disadvantage, pension scheme benefits are expressly excluded (however, see below regarding recent Government consultations). So, if a 
disabled person works fewer hours because of their disability, and therefore earns less money than an able-bodied person, the employer will not need to compensate the disabled individual. Equally, if the disabled person had been refused access to certain benefits under the pension scheme (for example because his or her health presents a high risk of having to claim the benefit) then the employer does not need to increase another part of his overall remuneration package.

A couple of consultation papers have been issued by the Government, looking at how to transpose the Employment Directive (2000/78/EC) into UK law. The most recent consultation paper proposes that employers be required to make reasonable adjustments for particular disabled people where they are responsible for setting the scheme rules and those rules cause a substantial disadvantage. Pension managers, trustees and insurers will have to justify the way in which they fulfil their responsibilities under the scheme in an objective way (for example, by using actuarial advice). The Government plans to make these changes in October 2004.

\section{Fixed-term employees}

The Employment Act 2002 includes protection for fixed-term employees. Under Council Directive 99/70/EC, fixed-term workers are not supposed to be treated less favourably than other types of worker. The UK Government took the view that pay and pensions were exempt from that requirement but, following consultation, decided to bring pay and pensions within the scope of the UK laws, which took effect from 1st October, 2002. As this was a voluntary extension of the protection required by the directive, the Government decided to restrict the UK legislation to fixed term employees (people who have a contract of service or apprenticeship, whether express or implied) as opposed to fixed-term workers (defined under the directive as people who have an employment contract or relationship entered into directly with an employer for a fixed term). Tribunals can look at the package of employment terms or compare each separate term for fixed term employees and permanent employees. Again, the different treatment can be defended if a good reason 'on objective grounds' can be given by the employer. It remains to be seen how scheme vesting periods will be viewed in the context of the UK legislation, although DTI guidance considers vesting periods to be acceptable if disapplying them would have a disproportionate cost or would be of no benefit to the fixed-term employee.

It is worth noting that employers must designate a stakeholder scheme for all employees (including fixed-term employees) who must wait for more than 12 months after becoming employed before they can join the employer's pension scheme. This has meant that several employers have opened their pension schemes to fixed-term employees so that they would not have to designate a stakeholder pension scheme.

\section{Sexual orientation}

Discrimination on the grounds of sexual orientation is not sex discrimination if gay men and gay women are treated in the same way. The Government has issued a couple of consultation papers to address, amongst other things, sexual orientation discrimination. The Government's consultation stems from the Employment Directive (2000/78/EC), which allows indirect discrimination if objectively justified by a legitimate aim and if the means of 
achieving that aim are appropriate and necessary. Pension schemes are most likely to discriminate on grounds of sexual orientation when a gay member dies and death benefits under the scheme are restricted to unmarried partners of the opposite sex. If the scheme requires the benefit to be paid to the member's spouse, however, the scheme will not be in breach of the directive as it allows schemes to impose requirements based on marital status and the UK

Government has said in its consultation papers that it intends to take advantage of this carve-out. UK legislation implementing the directive needs to be in place by 2 nd December, 2003.

\section{Age discrimination}

At the moment, there is no UK law against age discrimination and the Government does not plan to introduce age discrimination laws before the 2 nd December, 2006 deadline set by the Employment Directive. As with the other types of indirect discrimination dealt with by the Employment Directive, indirect age discrimination is allowed if objectively justified by a legitimate aim and if the means of achieving that aim are appropriate and necessary. The directive also exempts occupational pension schemes which fix the ages at which people can join the scheme or receive benefits, or which apply different age criteria for the purposes of actuarial calculations, so long as that treatment does not constitute sex discrimination. This exemption is expressed in rather woolly terms and has given rise to some concern that it will not allow schemes to pay different levels of benefit to people of different ages.

\section{Conclusion}

The workplace has never been the sole preserve of heterosexual, able-bodied, full-time, permanent workers of one sex. It is only recently, however, that steps have been taken in an attempt to address discrimination in its many forms. While it is laudable that there are laws designed to minimise discrimination where possible, it is the people running pension schemes (amongst others) who must grapple with the consequences of this huge body of ever-changing law.

Discrimination laws may be many things, but they are certainly not dull!

Bridget Murphy, Solicitor Mayer, Brown, Rowe \& Maw LLP

March 2003 